\title{
INDIKATOR LINGKUNGAN INTERN PADA KINERJA KEUANGAN DENGAN INTELLECTUAL CAPITAL DAN SIZE SEBAGAI VARIABEL MODERASI DAN MEDIASI
}

\author{
FETY ROCHYAWATI \\ Fakultas Ekonomi Sekolah Tinggai Ilmu Ekonomi YAPIS Merauke \\ Email: qudrat.mulya@yahoo.com
}

\begin{abstract}
Abstrak
The purpose of this study was to determine whether there the effect of trust, participation, strategic relevance towards financial performance, to determine whether firm size able to mediate the relationship between trust, participation, strategic relevance with financial performance and to determine whether intellectual capital able to moderate the relationship between trust, participation, strategic relevance with financial performance.

The research sample consisted of 60 respondents manufacturing industry. The methodof data collectionis done using purposive random sampling. The methodof hypothesis testingused is bivariate regression analysis, mediation regression dan regression moderation.

The result of this study showed that there the effect between trust and participation towards financial performance, while strategic relevance can not affect financial performance. Firm size not able to mediate the relationship between trust and strategic relevance with financial performance, while the relationship between participation with financial performance able mediated firm size. The relationship between trust, participation, strategic relevance with financial performance not able strengthened with intellectual capital.
\end{abstract}

Kata kunci: Trust, Participation, Strategic Relevance, Firm Size, Intellectual Capital, Financial Permormance.

\section{PENDAHULUAN}

Era globalisasi pada abad ini, persaingan bisnis semakin ketat memaksa sebagian besar perusahaan untuk meningkatkan aset yang dimilikinya untuk bisa mendapatkan laba yang besar. Salah satu masalah utama yang dihadapi oleh pimpinan atau pemilik perusahaan ialah penyediaan modal yang diperlukan untuk menunjang kegiatan-kegiatan perusahaan. Sumber terpenting dan kekayaan terpenting perusahaan telah berganti dari aset berwujud menjadi intellectual capital atau modal intelektual yang bertujuan untuk membangun, mengembangkan dan mempertahankan berdirinya sebuah perusahaan.

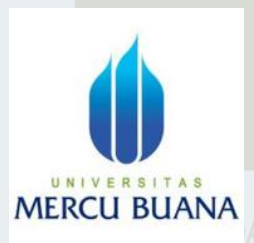

Jurnal Perilaku Dan Strategi bisnis

Vol.5 No.1, 2017

Hal. 1 - 20 Kapasitas intelektual dari sumber daya manusia yang dimiliki perusahaan dapat dilihat dari kualitas ide-ide, informasi, pengetahuan dan keahlian serta komitmen yang mereka miliki. Apabila kompetensi kompetensi yang dimiliki karyawan itu meperoleh peluang yang besar untuk mengaktualisasikan dan mengintegrasikannya ke dalam proses manajemen, maka modal intelektual ini diyakini akan meningkatkan kemampuan asset 
secara signifikan baik terhadap peningkatan profit, kinerja, kepuasan kerja, kepuasan pelanggan maupun pihak-pihak yang berkepentingan dalam perusahaan.

Mengelola suatu organisasi bisnis baik yang berorientasi pada profit maupun non profit ternyata tidak hanya tergantung pada besarnya modal finansial (financial capital) yang kita miliki atau semua jenis asset kasat mata lainnya. Dalam konteks perekonomian abad informasi, ada kenyataan lain yang lebih penting bagi perusahaan yaitu modal intelektual (intellectual capital). Kenyataan menunjukkan bahwa perusahaan-perusahaan multinasional yang menguasai perekonomian dunia, sangat tergantung pada modal intelektual pengetahuan, informasi, hak cipta intelektual, dan pengalaman yang dapat digunakan untuk menciptakan kekayaan (Stewart, 1997). Modal intelektual dapat diperoleh dari dua sumber, yaitu modal manusia dan modal struktural (Bontis et al., 1999).

Menurut Yuniasih (2010) modal intelektual (intellectual capital) merupakan topik yang baru berkembang beberapa tahun belakangan ini. Di Indonesia, fenomena intellectual capital (IC) mulai berkembang terutama setelah munculnya Pernyataan Standar Akuntansi Keuangan (PSAK) No. 19 (revisi 2000) tentang aktiva tidak berwujud. Menurut PSAK No. 19, aktiva tidak berwujud adalah aktiva nonmoneter yang dapat diidentifikasi dan tidak mempunyai wujud fisik serta dimiliki untuk digunakan dalam menghasilkan atau menyerahkan barang atau jasa, disewakan kepada pihak lainnya, atau untuk tujuan administratif (Ikatan Akuntan Indonesia, 2007).

Intellectual capital dalam perusahaan dapat digerakkan oleh trust, participation dan strategic relevance. Keberadaan trust diyakini dapat mengerakkan structural capital. Adanya saling kepercayaan antara lain akan menurunkan waktu yang diperlukan untuk menyelesaikan satu transaksi, menurunnya biaya per transaksi (Biljsma dan Koopman, 2003) dan terciptanya efisiensi (Partiwi, 2011). Lowendahl (1997) mengklasifikasikan modal intelektual dalam sebuah perusahaan menjadi sumber kompetensi dan kemampuan untuk bermitra/hubungan. Dalam hal ini karyawan diletakkan pada posisi sebagai patner strategis untuk bermitra dan berhubungan adalah sebuah partisipasi dan kontribusi karyawan dalam implementasi strategi perusahaan dalam kacamata sumberdaya manusia merupakan faktor yang penting dalam penciptaan intellectual capital di perusahaan. Kesuksesan suatu perusahaan dalam menghadapi suatu persaingan sangat bergantung pada strategi manajemen pengatahuan dari pada strategi pengalokasian asset fisik dan keuangan (Bontis et al., 1999), sehingga situasi pasar yang sangat kompetitif sekarang ini, penerapan strategi manajemen yang berbasis intelektual capital sangat penting untuk kesuksesan perusahaan. Wright et al., (2009) menemukan bahwa ukuran perusahaan berpengaruh positif terhadap kinerja. Semakin besar ukuran perusahaan, semakin tinggi pula tuntutan terhadap keterbukaan informasi dibanding perusahaan yang lebih kecil. Hasil penelitian menyatakan bahwa modal intelektual mempunyai pengaruh positif terhadap kinerja keuangan, bahkan modal intelektual bisa jadi indikator untuk kinerja keuangan masa depan (Chen et al., 2005). 


\section{PERTANYAAN PENELITIAN}

Berdasarkan latar belakang di atas, untuk menghindari kesalahan penafsiran maka penulis merumuskan masalah sebagai berikut:

1. Apakah terdapat pengaruh antara kepercayaan terhadap kinerja keuangan?

2. Apakah terdapat pengaruh antara partisispasi terhadap kinerja keuangan?

3. Apakah terdapat pengaruh antara relevansi strategis terhadap kinerja keuangan?

4. Apakah ukuran perusahaan mampu memediasi hubungan antara kepercayaan dengan kinerja keuangan?

5. Apakah ukuran perusahaan mampu memediasi hubungan antara partisipasi dengan kinerja keuangan?

6. Apakah ukuran perusahaan mampu memediasi hubungan antara relevansi strategis dengan kinerja keuangan?

7. Apakah intellectual capital mampu menguatkan hubungan antara kepercayaan dengan kinerja keuangan?

8. Apakah intellectual capital mampu menguatkan hubungan antara partisipasi dengan kinerja keuangan?

9. Apakah intellectual capital mampu menguatkan hubungan antara relevansi strategis dengan kinerja keuangan?

\section{TEORI DAN PENGEMBANGAN HIPOTESIS}

Ganesan (1994) mempelajari mengenai upaya membangun kepercayaan antara pemasok dengan pembeli dalam satu saluran distribusi. Pengaruh dari reputasi, kepuasan di masa lalu, pengalaman dengan mitra dan persepsi tentang investasi pihak lain yang dipergunakan dalam membina hubungan. Hasil studi ini menunjukkan bahwa dari perspektif pembeli reputasi supplier dan investasinya dalam membina hubungan tersebut merupakan hal yang penting dalam membangun kepercayaan. Dari sisi perspektif pemasok bahwa hanya kepuasan di masa lalu yang berpengaruh dalam membentuk kepercayaan pembeli. Dengan demikian kepercayaan dapat ditinjau sebagai komponen yang berharga dalam setiap keberhasilan menjalin hubungan dan lebih jauh berfungsi sebagai upaya untuk mengurangi risiko serta membangun hubungan jangka panjang dan meningkatkan komitmen Rusdin (2004).

Menurut Cohen dan Uphoff (1977), partisipasi adalah keterlibatan masyarakat dalam proses perencanaan dan pembuatan keputusan tentang apa yang dilakukan, dalam pelaksanaan program dan pengambilan keputusan untuk berkontribusi sumberdaya atau bekerjasama dalam organisasi atau kegiatan khusus, berbagi manfaat dari program pembangunan dan evaluasi program pembangunan. Margono Slamet (1985) menyatakan bahwa tumbuh dan berkembangnya partisipasi masyarakat dalam pembangunan, sangat ditentukan oleh adanya kemauan yang diberikan kepada masyarakat untuk berpartisipasi, adanya kesempatan masyarakat untuk berpartisipasi dan adanya kemampuan masyarakat untuk berpartisipasi. Robbins (1998) menyatakan pada hakikatnya kemampuan individu tersuusun dari dua perangkat faktor yaitu kemampuan intelektual dan kemampuan fisik.

Strategi hampir selalu dimulai dari apa yang dapat terjadi dan bukan dimulai dari apa yang terjadi. Terjadinya kecepatan inovasi pasar yang baru dan perubahan pola konsumen memerlukan kompetensi inti (core competencies). Perusahaan perlu mencari kompetensi inti 
di dalam bisnis yang dilakukan. Strategi mempunyai sebuah tingkatan yang merupakan kesatuan yang bulat dan menjadi isyarat bagi setiap pengambil keputusan tertinggi bahwa mengelola organisasi tidak boleh dilihat dari sudut kerapian administratif semata, tetapi juga hendaknya memperhitungkan soal "kesehatan" organisasi dari sudut ekonomi (J. Salusu, 1996). Dalam hal ini membentuk sebuah relevansi atau hubungan mitra sangat dibutuhkan dalam tahap tingkatan strategi agar diperoleh suatu keputusan-keputusan stratejik dan perencanaan stratejik yang sekaligus mampu menunjang berkembangnya organisasi ke tingkat yang lebih baik.

Menurut Ferry dan Jones (1979), ukuran perusahaan adalah suatu skala dimana dapat diklasifikasikan besar kecilnya perusahaan menurut berbagai cara, antara lain: total aktiva, penjualan, log size, nilai pasar saham, kapitalisasi pasar, dan lain-lain yang semuanya berkorelasi tinggi. Semakin besar total aktiva, penjualan, log size, nilai pasar saham, dan kapitalisasi pasar maka semakin besar pula ukuran perusahaan tersebut. Barth et al., (1998), menemukan bahwa ukuran perusahaan berhubungan negatif dengan laba. Hubungan negatif tersebut terjadi karena banyaknya informasi yang tersedia sepanjang tahun pada perusahaan-perusahaan besar, pada saat pengumuman laba, pasar kurang bereaksi.

Stewart (1997) mendefinisikan modal intelektual sebagai materi intelektual yaitu pengetahuan, informasi, kekayaan intelektual, pengalaman yang digunakan untuk menciptakan kesejahteraan. Menurut Hidayat (2000) modal intelektual telah menyebabkan pergeseran dalam paradigma melakukan bisnis, sumber kekuatan akan bergeser dari modal fisik menjadi sumber daya manusia, dari sumber daya alam menuju sumber daya pengetahuan, dari posisi sosial seseorang menjadi proses hubungan, dan dari kekuatan pemegang saham menjadi kekuatan pelanggan. Pergeseran paradigma yang muncul dalam teori pemasaran seperti fokus pada hubungan jangka panjang daripada transaksi pertukaran jangka pendek, membawa perbaikan yang signifikan bagi perusahaan. Melalui interaksi jangka panjang dengan konsumen perusahaan dapat memperoleh akses secara detail dan pengetahuan yang berguna tentang konsumen. Oleh karena itu konsumen yang loyal merupakan salah satu modal hubungan yang paling penting sehingga perusahaan harus menaruh perhatian lebih dalam masalah tersebut.

Sucipto (2003) pengertian kinerja keuangan adalah penentuan ukuran-ukuran tertentu yang dapat mengukur keberhasilan suatu organisasi atau perusahaan dalam menghasilkan laba. Suatu perusahaan bisa mengetahui bagaimana kondisi keuangan yang ada didalam perusahaan tersebut, apakah kondisi keuangan perusahaan dalam keadaan sehat atau dalam keadaan yang tidak sehat dapat dilakukan dengan pertimbanganpertimbangan, sehingga perusahaan dapat menentukan langkah yang sebaiknya ditempuh oleh perusahaan dalam posisi tersebut. Jika perusahaan dalam keadaan sehat maka sebaiknya perusahaan tetap mempertahankan posisi tersebut, namun jika dalam keadaan tidak sehat maka perusahaan perlu melakukan tindakan perubahan untuk mengatasi permasalahan yang ada di dalam perusahaan tersebut.

Dalam penelitian ini, penulis menggunakan acuan penelitian sebelumnya oleh (Linda Lestari, 2011) dalam penelitiannya yang berjudul analisis pengaruh kepercayaan, partisipasi, relevansi strategis terhadap kinerja keuangan dengan kinerja tidak berwujud sebagai variabel mediasi melakukan penelitian pada 72 UKM di desa Triharjo, Pandak, Bantul, 
Yogyakarta. Adapun tujuan dari penelitiannya adalah untuk mengetahui pengaruh kepercayaan, partisipasi, relevansi strategis terhadap kinerja keuangan dan kinerja tidak berwujud serta untuk mengetahui pengaruh kinerja tidak berwujud terhadap kinerja keuangan. Terdapat beberapa variabel dalam penelitian ini diantaranya variabel kepercayaan, partisipasi, relevansi strategis, kinerja keuangan, kinerja tidak berwujud. Penelitian tersebut dianalisis dengan metode uji validitas, uji reabilitas, uji normalitas, analisis hasil mahalanobis d-squared, analisis signifikasi probabilitas dan fungsi persamaan dan analisis model fit, sehingga dari hasil analisis tersebut diperoleh hasil uji hipotesis yang pertama menunjukkan faktor kepercayaan tidak berpengaruh terhadap kinerja tidak berwujud.

Hasil uji hipotesis kedua menunjukkan kepercayaan tidak berpengaruh terhadap kinerja keuangan. Hasil uji hipotesis ketiga mununjukkan partisipasi tidak berpengaruh terhadap kinerja tidak berwujud. Hasil hipotesis keempat menunjukkan partisipasi tidak berpengaruh terhadap kinerja keuangan. Hasil uji hipotesis kelima menunjukkan relevansi strategis berpengaruh terhadap kinerja tidak berwujud. Hasil uji hipotesis ketujuh menunjukkan kinerja tidak berwujud berpengaruh terhadap kinerja keuangan. Penelitian ini berbeda dengan penelitian sebelumnya yang dilakukan oleh Linda Lestari. Perbedaan terletak pada variabel yang digunakan, ada penambahan variabel moderasi dan perubahan variabel mediasi serta subyek yang diamati. Penelitian ini juga memiliki persamaan yang terletak pada variabel independen dan variabel dependen yang digunakan pada penelitian sebelumnya.

Menurut Anderson dan Narus (1990) kepercayaan merupakan keyakinan suatu perusahaan terhadap perusahaan lainnya bahwa perusahaan lain tersebut akan memberikan outcome yang positif bagi perusahaan. Outcome dalam hal ini dapat berupa keuntungan bagi perusahaan, dapat dikatakan bahwa semakin tinggi tingkat kepercayaan maka semakin tinggi pula kinerja keuangan perusahaan. Menurut Heller, et. al., 1984, partisipasi sebagai sebuah proses dimana individu mengambil bagian dalam pengambilan keputusan dalam sebuah institusi, program, dan lingkungan yang mempengaruhi mereka. Dalam hal ini perusahaan mencari sumber dana untuk mencukupi jumlah yang dibutuhkan dengan cara melibatkan seluruh anggota dalam melakukan pengambilan keputusan. Dapat dikatakan bahwa semakin kuat partisipasi semakin kuat pula kinerja keuangan perusahaan. Pengertian strategi adalah rencana yang disatukan, luas dan berintegrasi yang menghubungkan keunggulan strategis perusahaan dengan tantangan lingkungan, yang dirancang untuk memastikan bahwa tujuan utama dari perusahaan dapat dicapai melalui pelaksanaan yang tepat oleh organisasi (Glueck dan Jauch, 1989). Dapat dikatakan bahwa relevansi strategi adalah rencana yang disatukan, luas dan berintegrasi yang menghubungkan keunggulan strategis perusahaan dengan tantangan lingkungan, yang dirancang untuk memastikan bahwa tujuan utama dari perusahaan dapat dicapai melalui pelaksanaan yang tepat oleh organisasi dengan menjalankan mitra usahanya secara baik.

Keuntungan umum dari perusahaan jaringan dibandingkan dengan sebuah perusahaan tunggal berdasar hasil empiris Das dkk (2003) menunjukkan bahwa material aset dan yang tidak berwujud dianggap sebagai penyimpulan keberhasilan kemitraan yang strategis yang dapat dihasilkan dengan membangun kinerja berwujud. Dalam hal ini perusahaan mampu menciptakan strategi pengembangan perusahaan secara kuat dengan 
mitra usahanya sehingga perluasan pangsa pasarnya sangat luas dan mendorong perusahaan dalam menciptkan laba perusahaan yang tinggi. Dapat dikatakan bahwa semakin besar relevansi strategi semakin besar pula kinerja keuangan perusahaan. Dengan demikian, ada pengaruh antara kepercayaan, partisipasi dan relevansi strategis terhadap kinerja keuangan. Maka hipotesis yang diajukan dalam penelitian ini adalah:

$\mathrm{H} 1$ : Ada pengaruh antara kepercayaan terhadap kinerja keuangan.

$\mathrm{H} 2$ : Ada pengaruh antara partisipasi terhadap kinerja keuangan.

H3 : Ada pengaruh antara relevansi strategis terhadap kinerja keuangan.

Ukuran perusahaan adalah suatu skala dimana dapat diklasifikasikan besar kecil perusahaan menurut berbagai cara, antara lain: total aktiva, log size, nilai pasar saham, dan lain-lain. Pada dasarnya ukuran perusahaan hanya terbagi dalam tiga kategori yaitu perusahaan besar (large firm), perusahaan menengah (medium-size) dan perusahaan kecil (small firm). Penentuan ukuran perusahaan ini berdasarkan kepada total asset perusahaan Wright et al., (2009) menemukan bahwa ukuran perusahaan berpengaruh positif terhadap kinerja. Semakin besar ukuran perusahaan, semakin tinggi pula kinerja keuangan dibanding perusahaan yang lebih kecil. Telah dijelaskan juga bahwa semakin tinggi tingkat kepercayaan, partisipasi dan relevansi strategis maka semakin tinggi pula kinerja keuangan perusahaan. Dengan demikian, ukuran perusahaan mampu memediasi hubungan antara kepercayaan, partisipasi dan relevansi strategis dengan kinerja keuangan perusahaan. Maka hipotesis yang diajukan dalam penelitian ini adalah:

H4 : Ukuran perusahaan mampu memediasi hubungan antara kepercayaan dengan kinerja keuangan.

H5 : Ukuran perusahaan mampu memediasi hubungan antara partisispasi dengan kinerja keuangan.

H6 : Ukuran perusahaan mampu memediasi hubungan antara relevansi strategis dengan kinerja keuangan.

Petrash (1996) mencoba menjelaskan bahwa modal intelektual adalah modal manusia, modal organisasional dan modal pelanggan. Dalam penelitian ini, Intellectual capital dalam organisasi digerakkan oleh kepercayaan, partisipasi dan relevansi strategis. Trust mampu menggerakan human capital karena dengan adanya saling kepercayaan menyebabkan biaya monitoring dapat ditekan (Smith dan Barclay, 1997). Human capital ini merupakan elemen dari intellectual capital. Haanes dan Lowendahl (1997) mengklasifikasikan modal intelektual dalam sebuah perusahaan menjadi sumber kompetensi dan kemampuan untuk bermitra / hubungan. Bermitra / berhubungan merupakan bagian dari partisipasi. Joia (2000) menyatakan bahwa aktiva tak berwujud perusahaan berhubungan dengan strategi perusahaan. Aktiva tak berwujud itu berupa modal intelektual yang ada di perusahaaan tersebut. Kepercayaan, partisipasi dan relevansi strategis yang tinggi akan membuat suatu perusahaan membutuhkan sumber dana dalam jumlah yang besar sehingga membuat pengelolaan dan pemeliharaan intellectual capital menjadi semakin optimal serta akan menghasilkan kinerja intellectual capital yang lebih tinggi.

Belkaoui (2003) berpendapat bahwa investasi perusahaan dalam intellectual capital yang disajikan dalam laporan keuangan, dihasilkan dari peningkatan selisih antara nilai pasar dan nilai buku. Jadi, jika misalnya pasarnya efisien, maka investor akan memberikan nilai yang tinggi terhadap perusahaan yang memiliki IC lebih besar. Selain itu, jika IC 
merupakan sumber daya yang terukur untuk peningkatan competitive advantages, maka IC akan memberikan kontribusi terhadap kinerja keuangan serta meningkatkan nilai perusahaan (Chen et al., 2005). Dengan adanya pengelolaan dari kinerja intellectual capital sebagai nilai tambah di dalam perusahaan, dapat diketahui pula pengaruhnya terhadap kinerja keuangan. Apabila pengelolaan intellectual capital semakin baik maka kinerja keuangan akan dinilai semakin baik. Menurut Ulum (2007) IC diyakini dapat berperan penting dalam peningkatan nilai perusahaan maupun kinerja keuangan perusahaan. Tan et al., (2007) dalam penelitiannya telah membuktikan bahwa IC (VAIC ${ }^{\mathrm{TM}}$ ) berpengaruh secara positif terhadap kinerja keuangan perusahaan. Dengan menggunakan VAIC $^{\text {TM }}$ yang diformulasikan oleh Pulic (1998) sebagai ukuran kemampuan intelektual perusahaan (corporate intellectual ability). Dengan demikian, intellectual capital mampu menguatkan hubungan antara kepercayaan, partisipasi dan relevansi strategis dengan kinerja keuangan. Maka hipotesis yang diajukan dalam penelitian ini adalah:

H7 : Intellectual capital mampu menguatkan hubungan antara kepercayaan dengan kinerja keuangan.

H8 : Intellectual capital mampu menguatkan hubungan antara partisipasi dengan kinerja keuangan.

H9 : Intellectual capital mampu menguatkan hubungan antara relevansi strategis dengan kinerja keuangan.

\section{METODE PENELITIAN}

Metode sampling yang ditempuh menggunakan metode purposive random sampling, dimana sampel dibatasi pada elemen-elemen yang dapat membentuk informasi berdasarkan pertimbangan. Pertimbangan untuk responden adalah pimpinan atau yang mewakili yang bekerja di industri manufaktur Yogyakarta dengan menetapkan sampel sebesar 60 responden industri manufaktur. Adapun definisi operasional variabel yang digunakan dalam penelitian ini adalah sebagai berikut:

1. Kepercayaan $(K)$ adalah adanya pernyataan antara kedua belah pihak yang terlibat dalam suatu hubungan, salah satu pihak dianggap berperan sebagai controlling assets (memiliki sumber-sumber, pengetahuan) sementara pihak lainnya menilai bahwa berbagi penggunaan sumber-sumber tersebut dalam suatu ikatan akan memberikan manfaat (Moorman et al., 1993). Kepercayaan diukur dengan indikator pemenuhan kebutuhan dan keinginan, keterbukaan, daya terima, kemampuan pengetahuan, konsisten perilaku dan tindakan.

2. Partisipasi ( $P$ ) adalah proses pemberian peran kepada individu bukan hanya sebagai subyek melainkan sebagai aktor yang menetapkan tujuan, mengendalikan sumber daya dan mengarahkan proses yang mempengaruhi kehidupannya (Korten, 1988). Partisipasi diukur dengan indikator kemauan, kemampuan, keterlibatan dan kesempatan.

3. Relevansi strategis ( $R$ ) adalah cara untuk mencapai tujuan jangka panjang bisa berupa perluasan geografis, diversifikasi, akusisi, pengembangan produk, penetrasi pasar, rasionalisasi karyawan, divestasi, likuidasi dan joint venture (David, 2004). Relevansi strategis diukur dengan indikator komitmen tim, pengembangan produk, diskusi kelompok, perluasan geografis dan pangsa pasar. 
4. Ukuran perusahaan (U) adalah suatu skala dimana dapat diklasifikasikan besar kecilnya perusahaan menurut berbagai cara, antara lain: total aktiva, penjualan, log size, nilai pasar saham, kapitalisasi pasar, dan lain-lain yang semuanya berkorelasi tinggi (Ferry dan Jones, 1979). Ukuran perusahaan diukur dengan indikator total aktiva, hutang, penjualan, modal dan jumlah karyawan.

5. Intellectual capital (C) adalah materi intelektual (pengetahuan, informasi, properti intelektual, pengalaman) yang dapat digunakan untuk menciptakan kekayaan (Stewart, 1997). Intellectual capital diukur dengan indikator karyawan, ketrampilan, pengetahuan, informasi dan kerja sama.

6. Kinerja keuangan (KK) adalah penentuan ukuran-ukuran tertentu yang dapat mengukur keberhasilan suatu organisasi atau perusahaan dalam menghasilkan laba (Sucipto, 2003). Kinerja keuangan diukur dengan indikator likuiditas dan profitabilitas

Untuk memperoleh data-data yang digunakan dalam penelitian ini maka teknik yang digunakan dalam penelitian ini adalah teknik kuesioner yaitu teknik pengumpulan data dengan cara memberikan seperangkat pertanyaan atau pernyataan tertulis kepada responden untuk menjawabnya (Sugiyono, 2008). Pengukuran variabel penelitian dengan menggunakan skala likert yaitu skala yang digunakan untuk mengukur sikap, pendapat dan persepsi seseorang atau sekelompok orang tentang fenomena sosial. Jawaban setiap item instrumen yang menggunakan skala likert mempunyai gradasi dari sangat setuju sampai sangat tidak setuju, yaitu sebegai berikut:

$\begin{array}{ll}\text { Sangat Setuju (SS) } & \text { : skor } 5 \\ \text { Setuju (S) } & \text { : skor } 4 \\ \text { Netral (N) } & : \text { skor } 3 \\ \text { Tidak Setuju (TS) } & \text { : skor } 2 \\ \text { Sangat Tidak Setuju (STS) } & \text { : skor } 1\end{array}$

\section{HASIL PENELITIAN}

Tabel 1. Hasil Uji Validitas Kepercayaan, Partisipasi, Relevansi Strategis, Ukuran Perusahaan, Intellectual Capital dan Kinerja Keuangan

\begin{tabular}{ccrrl}
\hline Instrumen & Item & $\begin{array}{c}r- \\
\text { hitung }\end{array}$ & $\begin{array}{r}\text { r- } \\
\text { tabel }\end{array}$ & Kesimpulan \\
\hline \multirow{3}{*}{ Kepercayaan } & Item 1 & 0,609 & 0,25 & Valid \\
& Item 2 & 0,27 & 0,25 & Valid \\
& Item 3 & 0,41 & 0,25 & Valid \\
& Item 4 & 0,521 & 0,25 & Valid \\
& Item 5 & 0,354 & 0,25 & Valid \\
\hline \multirow{3}{*}{ Partisispasi } & Item 1 & 0,567 & 0,25 & Valid \\
& Item 2 & 0,781 & 0,25 & Valid \\
& Item 3 & 0,499 & 0,25 & Valid \\
& Item 4 & 0,386 & 0,25 & Valid \\
& Item 5 & 0,592 & 0,25 & Valid \\
\hline \multirow{5}{*}{ Relevansi Strategis } & Item 1 & 0,396 & 0,25 & Valid \\
& Item 2 & 0,455 & 0,25 & Valid \\
& Item 3 & 0,548 & 0,25 & Valid \\
& Item 4 & 0,577 & 0,25 & Valid
\end{tabular}




\begin{tabular}{llrrl} 
& Item 5 & 0,584 & 0,25 & Valid \\
\hline & Item 1 & 0,488 & 0,25 & Valid \\
& Item 2 & 0,596 & 0,25 & Valid \\
Ukuran Perusahaan & Item 3 & 0,458 & 0,25 & Valid \\
& Item 4 & 0,286 & 0,25 & Valid \\
& Item 5 & 0,284 & 0,25 & Valid \\
\hline \multirow{5}{*}{ Intellectual Capital } & Item 1 & 0,261 & 0,25 & Valid \\
& Item 2 & 0,566 & 0,25 & Valid \\
& Item 3 & 0,433 & 0,25 & Valid \\
& Item 4 & 0,318 & 0,25 & Valid \\
& Item 5 & 0,665 & 0,25 & Valid \\
\hline \multirow{5}{*}{ Kinerja Keuangan } & Item 1 & 0,38 & 0,25 & Valid \\
& Item 2 & 0,25 & 0,25 & Valid \\
& Item 3 & 0,435 & 0,25 & Valid \\
& Item 4 & 0,53 & 0,25 & Valid \\
& Item 5 & 0,585 & 0,25 & Valid \\
\hline
\end{tabular}

Sumber: Data Primer, diolah 2013

Tabel 1. menunjukkan bahwa nilai korelasi ( $r$-hitung) untuk masing-masing item pernyataan lebih besar atau sama dengan dari nilai r-tabel sebesar 0,25 (taraf signifikan 5\%; $n=60$ ), sehingga dapat disimpulkan bahwa item-item dari pernyatan tersebut dinyatakan valid dan dapat digunakan pengumpulan data.

Tabel 2. Hasil Uji Reliabilitas

\begin{tabular}{lrl}
\multicolumn{1}{c}{ Variabel } & Nilai Alpha & Keterangan \\
\hline Kepercayaan & 0,709 & Reliabel \\
Partisispasi & 0,762 & Reliabel \\
Relevansi Strategis & 0,746 & Reliabel \\
Ukuran Perusahaan & 0,708 & Reliabel \\
Intellectual Capital & 0,725 & Reliabel \\
Kinerja Keuangan & 0,716 & Reliabel \\
\hline \multicolumn{2}{l}{ Sumber: Data primer, diolah 2013}
\end{tabular}

Berdasarkan tabel di atas, semua variabel penelitian mempunyai nilai alpha lebih dari 0,6 maka dapat dikatakan bahwa semua instrumen tersebut reliabel.

Tabel 3. Hasil Uji Normalitas

\begin{tabular}{lr}
\hline \multicolumn{1}{c}{ Variabel } & Asymp. Sig. (2tailed) \\
\hline Kepercayaan (K) & 0,899 \\
Partisipasi (P) & 0,418 \\
Relevansi strategi (R) & 0,084 \\
Kinerja keuangan (KK) & 0,107 \\
\hline
\end{tabular}

Sumber: Data primer, diolah 2013

Hasil uji KOLMOGOROV-SMIRNOV dapat dilihat bahwa nilai Asymp. Sig. (2tailed) dari semua variabel lebih dari 0,05, maka sesuai ketentuan nilai Asymp. Sig. (2tailed) $>0,05$ maka nilai residual tersebut adalah berdistribusi normal. Dengan demikian dapat disimpulkan bahwa berdasarkan hasil uji diketahui bahwa model tidak terkena masalah normalitas.

Tabel 4. Hasil Uji Multikoleniaritas

\begin{tabular}{|c|c|c|}
\hline \multirow[t]{2}{*}{ Variabel } & \multicolumn{2}{|c|}{ Collinearity Statistics } \\
\hline & Tolerance & VIF \\
\hline Kepercayaan (K) & 0,780 & 1,282 \\
\hline
\end{tabular}




\begin{tabular}{lll}
\hline Partisipasi (P) & 0,867 & 1,154 \\
Relevansi strategi (R) & 0,818 & 1,222 \\
\hline
\end{tabular}

a. Dependent Variable: kinerja keuangan (KK)

Sumber: Data primer, diolah 2013

Dari tabel dapat dilihat nilai VIF untuk semua variabel independen masih lebih kecil dari pada 10 (nilai VIF < 10) dan nilai Tolerance untuk semua variabel independen lebih besar dari pada 0,1 (nilai Tolerance $>0,1$ ). Maka dapat disimpulkan dari ketiga variabel tidak terjadi gejala Multikolinieritas.

Hasil dari uji autokerelasi dapat dilihat dari tabel data primer yang diolah menggunakan SPSS 16.00 uji gejala autokorelasi dengan melihat hasil Durbin-Watson yang nilainya sebesar 1,748 . Nilai pada selang $1,65<1,748<2,35$, sehingga menurut pengujian Durbin Watson (DW) maka tidak ada gejala autokorelasi.

Tabel 5. Hasil Uji Heteroskedastisitas

\begin{tabular}{lc}
\hline \multicolumn{1}{c}{ Variabel } & Sig \\
\hline (Constant) & 0,286 \\
Kepercayaan (K) & 0,429 \\
Partisipasi (P) & 0,329 \\
Relevansi strategi (R) & 0,484 \\
\hline
\end{tabular}

a. Dependent Variable: RES2

Sumber: Data primer, diolah 2013

Dari tabel di atas dapat diketahui bahwa nilai signifikansi ketiga variabel independen lebih dari 0,05. Dengan demikian dapat disimpulkan bahwa tidak terjadi masalah heteroskedastisitas pada model regresi.

Hasil dari analisis regresi sederhana pada penelitian ini adalah hubungan antara kepercayaan terhadap kinerja keuangan, partisipasi terhadap kinerja keunangan dan relevansi strategis terhadap kinerja keuangan.

Tabel 6. Koefisien Regresi Kepercayaan terhadap Kinerja Keuangan

\begin{tabular}{|c|c|c|c|}
\hline Model & Unstandardized Coefficients & $\mathrm{T}$ & Sig \\
\hline & B & & \\
\hline $\begin{array}{l}\text { (Constant) } \\
\text { Kepercavaan (K) }\end{array}$ & $\begin{array}{r}13,100 \\
0,357\end{array}$ & $\begin{array}{l}4,923 \\
2,667\end{array}$ & $\begin{array}{l}0,000 \\
0,010\end{array}$ \\
\hline
\end{tabular}

a. $\quad$ Dependent Variable: kinerja keuangan (KK)

Sumber: Data primer, diolah 2013

Dari tabel di atas, maka diperoleh persamaan regresi sederhana sebagai berikut.

$\mathrm{KK}=13,100+0,357 \mathrm{~K}+\mathrm{e} 1$

Persamaan tersebut dapat diinterprestasikan bahwa nilai konstanta sebesar 13,100 menunjukkan bahwa apabila tidak ada kepercayaan maka kinerja kinerja keuangan akan tetap sebesar 13,100.

Koefisisen regresi kepercayaan sebesar 0,357 menunjukkan bahwa kepercayaan mempunyai hubungan positif dengan kinerja keuangan. Artinya semakin baik kepercayaan maka kinerja keuangan semakin baik juga. Sebaliknya, semakin rendah kepercayaan maka kinerja keuangan akan semakin rendah juga.

Nilai t hitung sebesar 2,667 dan nilai sig sebesar 0,010 yang lebih kecil dari 0,05 menunjukkan bahwa ada pengaruh yang signifikan antara kepercayaan dengan kinerja keuangan. 
Tabel 7. Koefisien Regresi Partisipasi terhadap Kinerja Keuangan

\begin{tabular}{lrrrr}
\hline \multirow{2}{*}{ Model } & \multicolumn{2}{c}{ Unstandardized Coefficients } & \multirow{2}{*}{ S } & Sig \\
\cline { 2 - 3 } & \multicolumn{1}{c}{ B } & & \\
\hline (Constant) & 15,505 & 6,823 & 0,000 \\
Partisipasi (P) & 0,240 & 2,064 & 0,043 \\
\hline
\end{tabular}

a. Dependent Variable: kinerja keuangan (KK)

Sumber: Data primer, diolah 2013

Dari tabel di atas, maka diperoleh persamaan regresi sederhana sebagai berikut.

$\mathrm{KK}=15,505+0,240 \mathrm{P}+\mathrm{e} 2$

Persamaan tersebut dapat diinterprestasikan bahwa nilai konstanta sebesar 15,505 menunjukkan bahwa apabila tidak ada partisipasi maka kinerja kinerja keuangan akan tetap sebesar 15,505.

Koefisisen regresi kepercayaan sebesar 0,240 menunjukkan bahwa partisipasi mempunyai hubungan positif dengan kinerja keuangan. Artinya semakin baik partisipasi maka kinerja keuangan semakin baik juga. Sebaliknya, semakin rendah partisipasi maka kinerja keuangan akan semakin rendah juga.

Nilai $t$ hitung sebesar 2,064 dan nilai sig sebesar 0,043 yang lebih kecil dari 0,05 menunjukkan bahwa ada pengaruh yang signifikan antara partisipasi dengan kinerja keuangan.

Tabel 8. Koefisien Regresi Relevansi Strategis terhadap Kinerja Keuangan

\begin{tabular}{lrrrr}
\hline \multirow{2}{*}{ Model } & \multicolumn{2}{c}{ Unstandardized Coefficients } & \multirow{2}{*}{ T } & Sig \\
\cline { 2 - 3 } & $\mathrm{B}$ & & \\
\hline (Constant) & 15,136 & 5,434 & 0,000 \\
Relevansi Strategis (R) & 0,244 & 1,812 & 0,075 \\
\hline
\end{tabular}

a. Dependent Variable: kinerja keuangan

Sumber: Data primer, diolah 2013

Dari tabel di atas, maka diperoleh persamaan regresi sederhana sebagai berikut.

$\mathrm{KK}=15,136+0,244 \mathrm{R}+\mathrm{e} 3$

Persamaan tersebut dapat diinterprestasikan bahwa nilai konstanta sebesar 15,136 menunjukkan bahwa apabila tidak ada relevansi strategis maka kinerja kinerja keuangan akan tetap sebesar 15,136.

Koefisisen regresi kepercayaan sebesar 0,244 menunjukkan bahwa relevansi strategis mempunyai hubungan positif dengan kinerja keuangan. Artinya semakin baik relevansi strategis maka kinerja keuangan semakin baik juga. Sebaliknya, semakin rendah relevansi strategis maka kinerja keuangan akan semakin rendah juga.

Nilai $\mathrm{t}$ hitung sebesar 1,812 dan nilai sig sebesar 0,075 yang lebih besar dari 0,05 menunjukkan bahwa tidak ada pengaruh yang signifikan antara relevansi strategis dengan kinerja keuangan.

Hasil dari analisis resgresi dengan variabel mediasi pada penelitian ini adalah hubungan antara kepercayaan terhadap kinerja keuangan, partisipasi terhadap kinerja keunangan dan relevansi strategis terhadap kinerja keuangan dengan ukuran perusahaan sebagai variabel mediasi. Hasil uji regresi mediasi antara kepercayaan terhadap kinerja keuangan dengan ukuran perusahaan sebagai variabel mediasi pada hipotesis keempat dapat dilihat pada tabel berikut. 
Tabel 9. Koefisien Regresi Kepercayaan terhadap Kinerja Keuangan dengan Ukuran Perusahaan sebagai Variabel Mediasi

\begin{tabular}{lrrr}
\hline \multicolumn{1}{c}{ Model } & \multicolumn{2}{c}{ Unstandardized Coefficients } & \multirow{2}{*}{ Sig } \\
\cline { 2 - 3 } & $\mathrm{B}$ & \\
\hline (Constant) & 11,621 & 0,001 \\
Kepercayaan (K) & 0,357 & 0,009 \\
Ukuran perusahaan (U) & 0,089 & 0,419 \\
\hline
\end{tabular}

a. Dependent Variable: kinerja keuangan (KK)

Sumber: Data primer, diolah 2013

Pada tabel diatas, diperoleh persamaan regresi mediasi sebagai berikut.

$\mathrm{KK}=11,621+0,357 \mathrm{~K}+0,089 \mathrm{U}+\mathrm{e} 4$

Pada tabel diatas, ditemukan bahwa kepercayaan berpengaruh signifikan pada kinerja keuangan, nilai sig lebih kecil dari 0,05 $(0,009<0,05)$. Ukuran perusahaan tidak berpengaruh signifikan dengan kinerja keuangan, nilai sig lebih besar $0,05(0,419>0,05)$. Sehingga dapat dikatakan bahwa ukuran perusahaan tidak dapat memediasi pengaruh antara kepercayaan terhadap kinerja keuangan.

Tabel 10. Koefisien Regresi Partisipasi terhadap Kinerja Keuangan dengan Ukuran Perusahaan sebagai Variabel Mediasi

\begin{tabular}{lrrr}
\hline \multirow{2}{*}{ Model } & \multicolumn{2}{c}{ Unstandardized Coefficients } & \multirow{2}{*}{ Sig } \\
\cline { 2 - 3 } & $\mathrm{B}$ & \\
\hline (Constant) & 11,377 & \\
Partisipasi (P) & 0,345 & 0,001 \\
Ukuran perusahaan $(\mathrm{U})$ & 0,128 & 0,005 \\
\hline
\end{tabular}

a. Dependent Variable: kinerja keuangan (KK)

Sumber: Data primer, diolah 2013

Pada tabel diatas, diperoleh persamaan regresi mediasi sebagai berikut.

$\mathrm{KK}=11,377+0,345 \mathrm{P}+0,128 \mathrm{U}+\mathrm{e} 5$

Pada tabel diatas, ditemukan bahwa partisipasi berpengaruh signifikan pada kinerja keuangan, nilai sig lebih kecil dari $0,05(0,001<0,05)$. Ukuran perusahaan berpengaruh signifikan dengan kinerja keuangan, nilai sig lebih kecil 0,05 $(0,005<0,05)$. Sehingga dapat dikatakan bahwa ukuran perusahaan dapat memediasi pengaruh antara partisipasi terhadap kinerja keuangan. .

Tabel 11. Koefisien Regresi Relevansi Strategis terhadap Kinerja Keuangan dengan Ukuran Perusahaan sebagai Variabel Mediasi

\begin{tabular}{llrl}
\hline \multirow{2}{*}{ Model } & \multicolumn{2}{c}{ Unstandardized Coefficients } & \multirow{2}{*}{ Sig } \\
\cline { 2 - 3 } & $\mathrm{B}$ & \\
\hline (Constant) & 13,601 & 0,000 \\
Relevansi Strategis (R) & 0,266 & 0,051 \\
Ukuran perusahaan (U) & 0,067 & 0,550 \\
\hline
\end{tabular}

a. Dependent Variable: kinerja keuangan (KK)

Sumber: Data primer, diolah 2013

Pada tabel diatas, diperoleh persamaan regresi mediasi sebagai berikut.

$\mathrm{KK}=13,601+0,266 \mathrm{R}+0,067 \mathrm{U}+\mathrm{e} 6$

Pada tabel diatas, ditemukan bahwa relevansi strategis tidak berpengaruh signifikan pada kinerja keuangan, nilai sig lebih besar 0,05 $(0,051>0,05)$. Ukuran perusahaan berpengaruh tidak signifikan dengan kinerja keuangan, nilai sig lebih besar $0,05(0,550>0,05)$. 
Sehingga dapat dikatakan bahwa ukuran perusahaan tidak dapat memediasi pengaruh antara partisipasi terhadap kinerja keuangan.

Hasil dari Moderated Multiple Regression (MMR) pada penelitian ini adalah hubungan antara kepercayaan terhadap kinerja keuangan, partisipasi terhadap kinerja keunangan dan relevansi strategis terhadap kinerja keuangan dengan intellectual capital sebagai variabel moderasi.

Tabel 12. Koefisien Regresi Kepercayaan terhadap Kinerja Keuangan dengan Intellectual Capital sebagai Variabel Moderasi

\begin{tabular}{lrrr}
\hline \multirow{2}{*}{ Model } & \multicolumn{2}{c}{ Unstandardized Coefficients } & \multirow{2}{*}{ Sig } \\
\cline { 2 - 3 } & \multicolumn{1}{c}{$\mathrm{B}$} & \\
\hline (Constant) & 20,379 & 0,331 \\
Kepercayaan (K) & $-0,405$ & 0,702 \\
Intellectual capital(C) & $-0,245$ & 0,820 \\
Interaksi Kepercayaan dan & & 0,033 & 0,543 \\
Intellectual Capital (KC) & & \\
\hline
\end{tabular}

a. Dependent Variable: kinerja keuangan (KK)

Sumber: Data primer, diolah 2013

Tabel diatas, diperoleh persamaan regresi moderasi sebagai berikut:

$\mathrm{KK}=20,379-0,405 \mathrm{~K}-0,245 \mathrm{C}+0,033 \mathrm{KC}+\mathrm{e} 7$

Pada tabel diatas, terlihat kepercayaan tidak berpengaruh signifikan dengan kinerja keuangan, ditunjukkan dengan nilai sig $(0,702>0,05)$. Selain itu terlihat intellectual capital juga tidak berpengaruh signifikan dengan kinerja keuangan, ditunjukkan dengan nilai sig $(0,820>0,05)$. Kemudian nilai sig interaksi antara kepercayaan dan intellectual capital sebesar 0,543 >0,05, menunjukkan bahwa intellectual capital tidak dapat menguatkan hubungan antara kepercayaan dengan kinerja keuangan.

Tabel 13 Koefisien Regresi Partisipasi terhadap Kinerja Keuangan dengan Intellectual Capital sebagai Variabel Moderasi

\begin{tabular}{lrrr}
\hline \multicolumn{1}{c}{ Model } & \multicolumn{2}{c}{ Unstandardized Coefficients } & \multirow{2}{*}{ Sig } \\
\cline { 2 - 3 } & $\mathrm{B}$ & \\
\hline (Constant) & 20,180 & 0,144 \\
Partisipasi (P) & $-0,425$ & 0,547 \\
Intellectual capital(C) & $-0,155$ & 0,840 \\
Interaksi Partisipasi dan & 0,030 & 0,440 \\
Intellectual capital (PC) & & \\
\hline
\end{tabular}

a. Dependent Variable: kinerja keuangan (KK)

Sumber: Data primer, diolah 2013

Tabel diatas, diperoleh persamaan regresi moderasi sebagai berikut.

$\mathrm{KK}=20,180-0,425 \mathrm{P}-0,155 \mathrm{C}+0,030 \mathrm{PC}+\mathrm{e} 8$

Pada tabel diatas, terlihat partisipasi tidak berpengaruh signifikan dengan kinerja keuangan, ditunjukkan dengan nilai sig $(0,547>0,05)$. Selain itu terlihat intellectual capital juga tidak berpengaruh signifikan dengan kinerja keuangan, ditunjukkan dengan nilai sig $(0,840>$ $0,05)$. Kemudian nilai sig interaksi antara partisispasi dan intellectual capital sebesar 0,440 > 0,05 , menunjukkan bahwa intellectual capital tidak dapat menguatkan hubungan antara partisipasi dengan kinerja keuangan. 
Tabel 14. Koefisien Regresi Relevansi Strategis terhadap Kinerja Keuangan dengan Intellectual Capital sebagai Variabel Moderasi

\begin{tabular}{lrrr}
\hline \multicolumn{1}{c}{ Model } & \multicolumn{2}{c}{ Unstandardized Coefficients } & \multirow{2}{*}{ Sig } \\
\cline { 2 - 3 } & $\mathrm{B}$ & \\
\hline (Constant) & 13,131 & 0,515 \\
Relevansi Strategis (R) & $-0,071$ & 0,943 \\
Intellectual capital (C) & 0,196 & 0,852 \\
Interaksi Relevansi Strategi & 0,012 & 0,813 \\
dan Intellectual capital (RC) & & \\
\hline
\end{tabular}

a. Dependent Variable: kinerja keuangan (KK)

Sumber: Data primer, diolah 2013

Tabel diatas, diperoleh persamaan regresi moderasi sebagai berikut.

$\mathrm{KK}=13,131-0,071 \mathrm{R}+0,196 \mathrm{C}+0,012 \mathrm{RC}+\mathrm{e} 9$

Pada tabel diatas, terlihat relevansi strategis tidak berpengaruh signifikan dengan kinerja keuangan, ditunjukkan dengan nilai sig $(0,943>0,05)$. Selain itu terlihat intellectual capital juga tidak berpengaruh signifikan dengan kinerja keuangan, diyunjukkan dengan nilai sig $(0,852>0,05)$. Kemudian nilai sig interaksi antara relevansi strategis dan intellectual capital sebesar 0,813 >0,05, menunjukkan bahwa intellectual capital tidak dapat menguatkan hubungan antara relevansi strategis dengan kinerja keuangan.

\section{PEMBAHASAN}

Berdasarkan hasil analisis data tentang Analisis Pengaruh Kepercayaan, Partsipasi, Relevansi Strategis terhadap Kinerja Keuangan dengan ukuran perusahaan sebagai variabel mediasi dan intellectual capital sebagai variabel moderasi, dapat dibuat pembahasan sebagai berikut.

Hipotesis pertama yang menyatakan bahwa ada pengaruh antara kepercayaan terhadap kinerja keuangan, diterima. Hal ini ditunjukkan oleh nilai signifikansi yang lebih kecil dari $0,05(0,010<0,05)$. Semakin tinggi kepercayaan suatu perusahaan maka akan semakin tinggi pula kinerja keuangan pada perusahaan. Dengan demikian kinerja keuangan di industri manufaktur DIY ditentukan oleh kepercayaan industri. Secara langsung kepercayaan akan mempengaruhi kinerja keuangan. Kepercayaan adalah suatu keadaan sebagai hasil hubungan yang terbangun dalam jangka waktu tertentu misal kepercayaan dengan konsumen dan kepercayaan dengan karyawan. Konsumen akan setia pada perusahaan, merek atau produk yang telah mereka percaya dalam artian konsumen akan mempercayai perusahaan ketika ada cukup bukti dan alasan bahwa produk yang dikeluarkan pada perusahaan tersebut sungguh layak untuk dipercaya. Dengan adanya kepercayaan juga akan menciptakan rasa aman dan kredibel dan mengurangi persepsi konsumen akan resiko dalam pertukaran. Sehingga dengan adanya kepercayaan akan meningkatkan konsumen terhadap pembelian produk yang nantinya akan berdampak pada kinerja keuangan perusahaan. Kaitannya kepercayaan dengan karyawan adalah karyawan mengetahui isu-isu penting dengan lingkungan luar. Karyawan terbuka terhadap perusahaan tentang isu-isu penting diluar misalkan tentang harga jual produk dan kualitas produk perusahaan yang berkaitan dengan keuangan sehingga dapat dijadikan sebagai bahan perbaikan yang nantinya perusahaan dapat menargetkan laba perusahaan. 
Hipotesis kedua yang menyatakan bahwa ada pengaruh antara partisipasi terhadap kinerja keuangan, diterima. Hal ini ditunjukkan oleh nilai signifikansi yang lebih kecil dari 0,05 $(0,043<0,05)$. Semakin tinggi partisipasi suatu perusahaan maka akan semakin tinggi pula kinerja keuangannya. Dengan demikian kinerja keuangan di industri manufaktur DIY ditentukan oleh partisipasi. Signifikannya pengaruh partisipasi terhadap kinerja keuangan disebabkan karena saran dan kritik dari karyawan dapat dijadikan pertimbangan dalam pelaksanaan keputusan perusahaan. Seperti yang kita ketahui dalam membuat suatu keputusan perusahaan dengan cara melibatkan beberapa karyawan. Hal yang demikian inilah yang sangat menjadi pertimbangan dalam melakukan keputusan perusahaan, misalnya tentang tanggapan harga produk atau kualitas produk yang nantinya berhubungan dengan laba perusahaan.

Hipotesis ketiga yang menyatakan bahwa ada pengaruh antara relevansi strategis terhadap kinerja keuangan, ditolak. Hal ini ditunjukkan oleh nilai signifikansi yang lebih besar dari $0,05(0,075>0,05)$. Semakin tinggi relevansi strategis suatu perusahaan maka akan semakin rendah kinerja keuangan pada perusahaan. Dengan demikian kinerja keuangan di industri manufaktur DIY tidak ditentukan oleh relevansi strategis karyawan terhadap pimpinan. Tidak signifikannya pengaruh relevansi strategis terhadap kinerja keuangan karena perusahaan tidak memperluas pangsa pasar dengan mitra usahanya. Hal ini disebabkan karena obyek penelitian sebagian besar pada UKM (Usaha Kecil Menengah) yang dominan mempunyai satu tempat perusahaan dan tidak mengembangkan produk yang dihasilkan dengan mitra usahanya melainkan hanya ke konsumen saja. Walaupun tidak memperluas pangsa pasar dengan mitra usahanya, keuangan perusahaan tetap berjalan baik dan mencapai tingkat keuntungan yang tinggi.

Hipotesis keempat yang menyatakan bahwa ukuran perusahaan mampu memediasi hubungan antara kepercayaan terhadap kinerja keuangan, ditolak. Hal ini ditunjukkan oleh nilai signifikansi yang lebih besar dari 0,05 $(0,419>0,05)$. Semakin tinggi kepercayaan maka akan semakin tinggi kinerja keuangan, semakin tinggi kinerja keuangan maka semakin tinggi pula ukuran perusahaan. Tidak signifikannya ukuran perusahaan mampu memediasi hubungan antara kepercayaan terhadap kinerja keuangan disebabkan karena jumlah karyawan yang lebih dari 100 orang, tidak menentukan ukuran perusahaan. Karena dalam obyek penelitian ini sebagian besar adalah UKM maka ukuran perusahaan dengan jumlah karyawan yang tinggi tidak dapat dijadikan sebagai ukuran perusahaan. Dalam konteksnya, UKM yang karyawannya kurang lebih terdiri dari 1-25 orang saja, bisa menjalankan usahanya dengan baik. Jika jumlah karyawannya semakin banyak, maka kepercayaan suatu perusahaan tidak dapat berjalan mungkin karena adanya beberapa karyawan yang tidak konsisten dalam menjalankan tugas dalam pembuatan produk yang tidak terselesaikan dan tidak adanya pemantauan khusus dari petugas, sehingga produktivitas perusahaan akan menurun yang nantinya akan mengahambat kinerja keuangan.

Hipotesis kelima yang menyatakan bahwa ukuran perusahaan mampu memediasi pengaruh partisipasi terhadap kinerja keuangan, diterima. Hal ini ditunjukkan oleh nilai signifikansi yang lebih kecil dari 0,05 $(0,005<0,05)$. Semakin tinggi partisipasi maka akan semakin tinggi kinerja keuangan, semakin tinggi kinerja keuangan maka semakin tinggi pula ukuran perusahaan. Signifikannya ukuran perusahaan mampu memediasi hubungan antara partisipasi terhadap kinerja keuangan disebabkan karena pentingnya melihat volume 
penjualan untuk menentukan ukuran suatu perusahaan. Dalam menjalankan bisnisnya, suatu perusahaan harus bisa menentukan target volume penjualan dengan merealisasikan keuangan di masa yang akan datang sehingga bila terjadi peningkatan volume penjualan, karyawan berperan aktif dalam kegiatan perusahaan khususnya memproduksi barang. Dengan meningkatnya volume penjualan maka akan meningkatkan keuntungan perusahaan. Hipotesis keenam yang menyatakan bahwa ukuran perusahaan mampu memediasi pengaruh relevansi strategis terhadap kinerja keuangan, ditolak. Hal ini ditunjukkan oleh nilai signifikansi yang lebih besar dari $0,05(0,550>0,05)$. Semakin tinggi relevansi strategis maka akan semakin tinggi kinerja keuangan, semakin tinggi kinerja keuangan maka semakin tinggi pula ukuran perusahaan. Tidak signifikannya ukuran perusahaan mampu memediasi pengaruh relevansi strategis terhadap kinerja keuangan disebabkan karena jumlah hutang dan nilai pasar saham biasa yang dimiliki suatu perusahaan tidak menceminkan ukuran perusahaan. Seperti telah diketahui bahwa objek penelitian ini sebagian besar UKM, maka UKM pada umumnya tidak menerapkan nilai pasar saham biasa dan jumlah hutang. Nilai saham pasar biasa digunakan pada perusahaan yang sudah go publik dan perusahaan yang telah mencapai likuiditasnya akan mendapatkan jumlah hutang. UKM sebagian besar dari hasil produk tidak menjalankan dengan mitra usahanya, bahkan sampai nilai saham pasar biasa ataupun jumlah hutang karena tergolong ke dalam usaha kecil menengah.

Hipotesis ketujuh menyatakan bahwa intellectual capital mampu menguatkan hubungan antara kepercayaan terhadap kinerja keuangan di industri manufaktur DIY, ditolak yang ditunjukkan oleh nilai sig sebesar $(0,543>0,05)$. Semakin tinggi kepercayaan maka akan semakin tinggi kinerja keuangan, semakin tinggi kinerja keuangan maka semakin tinggi pula intellectual capital. Intellectual capital adalah jumlah dari apa yang dihasilkan oleh tiga elemen utama organisasi (human capital, structural capital, customer capital) yang berkaitan dengan pengetahuan dan teknologi serta dapat memberikan nilai lebih bagi perusahaan berupa keunggulan bersaing dari suatu perusahaan. Karyawan memiliki banyak pengetahuan tentang pekerjaan yang perlu dilakukan merupakan bagian dari intellectual capital. Karena objek penelitian sebagian besar adalah UKM yang kaitannya dengan kinerja keuangan dalam usahanya tidak membutuhkan investor. Walaupun dengan tidak ada investor yang menanamkan modalnya pada perusahaan tetapi perusahaan dapat memperoleh keuntungan yang diinginkan dengan konsumen.

Hipotesis kedelapan menyatakan bahwa variabel intellectual capital tidak mampu menguatkan hubungan antara partisipasi terhadap kinerja keuangan di industri manufaktur DIY, tidak terbukti yang ditunjukkan oleh nilai sig sebesar $(0,440>0,05)$. Semakin tinggi partisipasi maka akan semakin tinggi kinerja keuangan, semakin tinggi kinerja keuangan maka semakin tinggi pula intellectual capital. Hal ini dikarenakan intellectual capital berupa kecerdasan, pengetahuan, komunikasi dan tingkat pendidikan karyawan sebagai sumber produktivitas karyawan dan pertumbuhan ekonomi bagi perusahaan. Karyawan tidak diberi kesempatan untuk memberikan pendapat tentang pengembangan solusi dalam memecahkan masalah perusahaan. Karena masalah pada suatu perusahaan sifatnya rahasia dan hanya terbatas pada anggota-anggota tertentu, jika masalah itu menyebar dikhawatirkan akan menurunkan brand image perusahaan, sehingga kinerja keuangan perusahaan akan terhambat. 
Hipotesis kesembilan menyatakan bahwa variabel intellectual capital tidak mampu menguatkan hubungan antara relevansi strategis terhadap kinerja keuangan di industri manufaktur DIY, tidak terbukti yang ditunjukkan oleh nilai sig sebesar $(0,813>0,05)$. Semakin tinggi relevansi strategis maka akan semakin tinggi kinerja keuangan, semakin tinggi kinerja keuangan maka semakin tinggi pula intellectual capital. Hal ini dikarenakan obyek yang diteliti sebagian besar berbentuk UKM (Usaha Kecil Menengah) sehingga tingkat kecerdasan seseorang, tingkat pengetahuan yang tinggi tidak berpengaruh pada perusahaan. Karyawan hanya dituntut untuk bergerak pasif mengikuti tugas pemimpin. Selain itu, karyawan juga tidak dapat mengembangkan produk, layanan, proses kepada mitra kerja karena dikhawatirkan akan menjadi dampak menurunnya kinerja keuangan perusahaan yang mungkin karyawan mempunyai inisiatif untuk mendirikan usaha seperti pada usaha perusahaan tempat bekerja.

\section{KESIMPULAN}

Berdasarkan hasil analisis dan pembahasan tentang Analisis Pengaruh Kepercayaan, Partsipasi, Relevansi Strategis terhadap Kinerja Keuangan dengan ukuran perusahaan sebagai variabel mediasi dan intellectual capital sebagai variabel moderasi, dapat disimpulkan sebagai berikut.

1. Hipotesis pertama menyatakan bahwa ada pengaruh antara kepercayaan terhadap kinerja keuangan, yang ditunjukkan oleh nilai signifikan sebesar $(0,010<0,05)$.

2. Pada hipotesis kedua juga menyatakan bahwa ada pengaruh antara partisipasi terhadap kinerja keuangan, yang ditunjukkan oleh nilai signifikan sebesar $(0,043<0,05)$.

3. Untuk hipotesis ketiga ternyata tidak ada pengaruh antara relevansi strategis terhadap kinerja keuangan, yang ditunjukkan oleh nilai signifikan sebesar $(0,075>0,05)$.

4. Sedangkan untuk hipotesis keempat menyatakan bahwa ukuran perusahaan tidak mampu memediasi hubungan antara kepercayaan dengan kinerja keuangan, yang ditunjukkan oleh nilai signifikan sebesar $(0,419>0,05)$.

5. Tetapi untuk hipotesis kelima menyatakan bahwa ukuran perusahaan mampu memediasi hubungan antara partisispasi dengan kinerja keuangan, yang ditunjukkan oleh nilai signifikan sebesar $(0,005<0,05)$.

6. Untuk hipotesis keenam ternyata hubungan antara relevansi strategis dengan kinerja keuangan tidak mampu dimediasi dengan ukuran perusahaan, yang ditunjukkan oleh nilai signifikan sebesar $(0,550>0,05)$.

7. Hipotesis ketujuh menyatakan bahwa hubungan antara kepercayaan dengan kinerja keuangan tidak mampu dikuatkan dengan intellectual capital, yang ditunjukkan oleh nilai signifikan sebesar $(0,543>0,05)$.

8. Pada hipotesis kedelapan menyatakan bahwa intellectual capital tidak mampu menguatkan hubungan antara partisipasi dengan kinerja keuangan, yang ditunjukkan oleh nilai signifikan sebesar $(0,440>0,05)$.

9. Hipotesis kesembilan juga menyatakan bahwa intellectual capital tidak mampu menguatkan hubungan antara relevansi strategis dengan kinerja keuangan, yang ditunjukkan oleh nilai signifikan sebesar $(0,813>0,05)$. 


\section{SARAN PENELITIAN YANG AKAN DATANG}

Berdasarkan hasil analisis dan pembahasan tentang Analisis Pengaruh Kepercayaan, Partisipasi, Relevansi Strategis terhadap Kinerj Keuangan dengan ukuran perusahaan sebagai variabel mediasi dan intellectual capital sebagai variabel moderasi, dapat disarankan sebagai berikut.

1. Berdasarkan hasil analisis dan kesimpulan, ternyata variabel relevansi strategi mempunyai pengaruh tidak signifikan terhadap variabel keuangan. Hal ini disebabkan karena obyek penelitian sebagian besar pada UKM yang sebagian besar tidak mengembangkan produk yang dihasilkan dengan mitra usahanya. Apabila pada obyek penelitian sebagian besar berupa industri maka diharapkan perusahaan mampu mengembangkan produknya dengan mitra usahanya secara baik, perusahaan mampu memperluas perusahaannya dengan mitra usahanya secara baik, perusahaan memiliki komitmen yang diperlukan untuk tim eksekutif dan pengurus dalam menjalankan kajian perencanaan strategis serta perusahaan mampu menciptakan strategi pengembangan perusahaan secara kuat dengan mitra usahanya sehingga perluasan pangsa pasarnya sangat luas.

2. Untuk variabel ukuran perusahaan ternyata tidak mempunyai pengaruh signifikan untuk memediasi hubungan antara kepercayaan dan relevansi strategis dengan kinerja keuangan. Karena dalam obyek penelitian ini sebagian besar adalah UKM maka ukuran perusahaan tidak mampu memediasi hubungan antara kepercayaan dan relevansi strategis dengan kinerja keuangan. Jika dalam obyek penelitian ini adalah industri maka diharapkan perusahaan mempunyai modal yang sangat kuat untuk membiayai perusahaan, pentingnya melihat volume penjualan dan jumlah hutang dan nilai pasar saham biasa yang dimiliki suatu perusahaan untuk menentukan ukuran suatu perusahaan serta memiliki total aktiva yang tinggi karena akan menarik investor untuk menanamkan modalnya pada perusahaan.

3. Pada variabel intellectual capital ternyata tidak mempunyai pengaruh signifikan yang menguatkan hubungan antara kepercayaan, partisipasi dan relevansi strategis dengan kinerja keuangan. Hal ini dikarenakan obyek yang diteliti sebagian besar berbentuk UKM sehingga intellectual capital ternyata tidak mampu menguatkan hubungan antara kepercayaan, partisipasi dan relevansi strategis dengan kinerja keuangan. Jika pada penelitian ini sebagian besar adalah industri maka diharapkan karyawan memiliki pengetahuan yang cukup dan keterampilan untuk menyelesaikan pekerjaan, karyawan menggunakan ide dan pengetahuan baru untuk mengembangkan solusi serta karyawan mampu bermitra dengan pelanggan / mitra aliansi lainnya untuk mengembangkan solusi yang natinya akan meningkatkan pertumbuhan ekonomi bagi perusahaan.

\section{DAFTAR PUSTAKA}

Anderson, J.C. and Narus, J.A., 1990, "A model of distributor firm and manufacturer working partnerships", Journal of Marketing, Vol. 54 No. 1, pp. 42-58.

Barth, M., W.Beaver dan W.Landsman, 1998, "Relative Valuation Roles of Equity Book Value and Net Income as a Function of Financial Health", Journal of Accounting and Economics: hal. 1-34.Bijlsma, $\mathrm{K}$ and P. Koopman, 2003, "Introduction: Trust within Organisation", Personnel Review, 32 (2), 543-556. 
Belkaoui, Ahmed Riahi, 2003, "Intellectual Capital and Firm Performance of US Multinational Firms: A Study of The Resource-based and Stakeholder Views", Journal of Intellectual Capital, Vol. 4, No. 2, pp. 215-226.

Bijlsma, K and P. Koopman, 2003, "Introduction: Trust within Organisation", Personnel Review, 32 (2), 543-556.

Bontis, N., Dragonetti, N., Jacobsen, K. and Roos, G., 1999, "The knowledge toolbox: a review of the tools available to measure and manage intangible resources", European Management Journal, Vol. 17 No. 4, pp. 391-402.

Chen, M.C., S.J. Cheng, Y. Hwang, 2005, "An empirical investigation of the relationship between intellectual capital and firms' market value and financial performance ", Journal of Intellectual Capital, Vol. 6 N0. 2, pp. 159-176.Ikatan Akuntan Indonesia, 2007, Standar Akuntansi Keuangan, Jakarta: Salemba Empat.

Das, T.K. and Teng, B.S., 1998, "Between trust and control: developing confidence in partner cooperation in alliances", Academy of Management Review, Vol. 23 No. 3, pp. 491-512.

David, Fred R., 2004, Manajemen Strategis, PT. Indeks kelompok Gramedia, Jakarta.

Ferry and Jones, 1979, "Determinants of Financial Strukture a New Methodological Approach", Jurnal of Finance, Vol. XXXIC, No. 3 June 1979.

Ganesan, Shankar, 1994, "Determinants of Long-Term Orientation in Buyer-Seller Relationship", Journal of Marketing, Vol.58, April, pp. 1-19.

Hidayat, 2000, "Peranan Strategis Modal Intelektual dalam Persaingan Bisnis dinEra Jasa", EKUITAS, Vol 5, No. 3, 293-312.

Ikatan Akuntan Indonesia, 2007, Standar Akuntansi Keuangan, Jakarta: Salemba Empat.

Lestari, Linda, 2011. Analisis Pengaruh Kepercayaan, Partisipasi, Relevansi Strategis Terhadap Kinerja Keuangan Dengan Kinerja Tidak Berwujud Sebagai Variabel Mediasi.

Moorman, Rohit Deshpande, dan Gerald Zaltman, 1993, "Factors Affecting Trust in Market Research Relationships", Journal of Marketing, Vol. 57, January, pp. 81-101.

Partiwi, Dwi Astuti dan Sabeni, Arifin, 2005, Hubungan Intellectual Capital dan Business Performance dengan Diamond Specification: Sebuah Perspektif Akuntansi, SNA VIII Solo.

Petrash, G., 1996, "Dow's journey to a knowledge value management culture", European Management Journal, Vol. 14, No. 4, pp. 365-73.

Pulic, A., 1998, "Measuring the performance of intellectual potential in knowledge economy", www.measuringip.at/Opapers/Pulic/Vaictxt.vaictxt.html (diakses tanggal 28 oktober 2013).

Stewart, T.A., 1997, Intellectual Capital. The New Wealth of Organization, Doubleday, New York, NY.

Sugiyono, 2008, Metode Penelitian Bisnis, Salemba Empat, Jakarta.

Tan, H. P., Plowman, D. and Hancock, P., 2007, "Intellectual capital and financial returns of companies", Journal of Intellectual Capital, Vol. 8, No. 1, pp. 76-94.

Ulum, I., 2007, "Pengaruh Intellectual Capital Terhadap Kinerja Keuangan Perusahaan Perbankan di Indonesia" Master Thesis, University of Diponegoro. 
Wright, Peter, Mark Kroll, Ananda Mukhreji, Michael L. Pettus, 2009, "Do the Conti-ngencies of External Monitoring, OwnershipIncentives, or Free Cash Flow Explain Opposing Firm Performance Expectations?", Journal Management Governance, 13, pp. 215243.

Yuniasih, 2010, Eksplorasi Kinerja Pasar Perusahaan: Kajian Berdasarkan Modal Intelektual (Studi Empiris Pada Perusahaan Keuangan Yang Terdaftar Di Bursa Efek Indonesia). 